\title{
Il linguaggio grafico e gli indizi pittorici per una comunicazione inclusiva dello spazio
}

\author{
Anna Lisa Pecora
}

Abstract

L'incremento di tour virtuali ultimamente ha subito una forte spinta, anche per ragioni di distanziamento dovute all'emergenza sanitaria. II tema dei nuovi media per la divulgazione del patrimonio, porta in primo piano le discipline della rappresentazione che possono porsi come guida per un'opportuna gestione del linguaggio figurativo. Qualsiasi sistema tecnologico che offra un'esperienza virtuale, immersiva o aumentata, richiede, infatti, un processo di figurazione che implica, necessariamente, un'interpretazione e una codifica delle informazioni spaziali in segni grafici. Questo iter presuppone una profonda conoscenza dei codici espressivi del disegno, al fine di gestire opportunamente le informazioni grafiche e dare efficacia al messaggio trasmesso. Tuttavia, non sempre se ne tiene conto, puntando l'attenzione su aspetti tecnologici e di spettacolarizzazione piuttosto che sull'utente. Una sommaria o errata progettazione dell'apparato grafico in un sistema di realtà virtuale (VR), può indurre sensazioni di malessere e incidere negativamente sui valori comunicativi. Scopo del presente paper è quello di analizzare nel dettaglio alcuni codici pittorici, basilari per l'interpretazione dello spazio e darne una lettura che si estende oltre il consueto ambito della neuro tipicità. Si mettono in campo aspetti che possono ampliare l'utenza di riferimento degli ambienti virtuali a un pubblico più debole, con risposte sensoriali che non sempre sono generalizzabili.

Parole chiave

rappresentazione, Pictorial Cues, autismo (ASD), comunicazione spaziale.
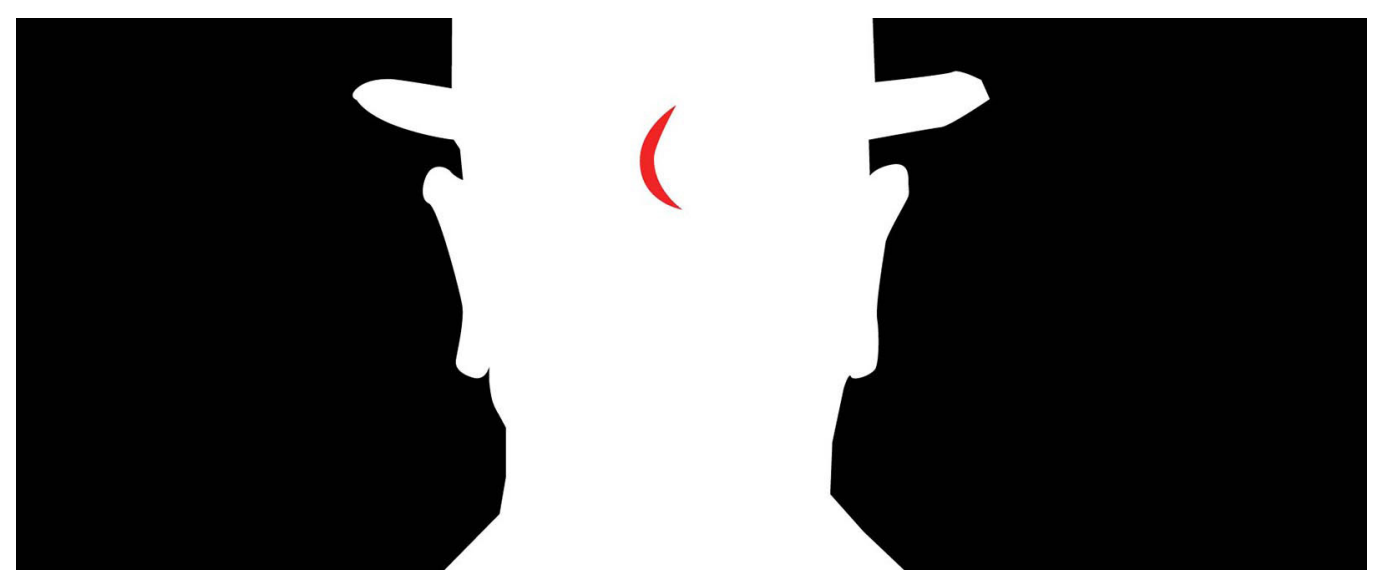


\section{Introduzione}

Un'immagine, sia che si tratti di un disegno, di una foto, di un render implica sempre un processo d'interpretazione che si sovrappone a quello da noi attuato durante l'iter visivo. Al di là delle differenze individuali, la tendenza della mente, in persone neuro tipiche, è quella di effettuare delle semplificazioni in base a categorie acquisite nel tempo attraverso le esperienze, in modo tale da leggere uno schema figurativo nella sua globalità. Questa capacità può mancare in casi di "agnosia" visiva, frequentemente riscontrata nell'autismo. Solitamente in questi casi, una tendenza diffusa è quella di concentrarsi sui dettagli; questa propensione può anche portare a una sovversione di alcuni dei processi percettivi approfonditi dalla Gestalt. È quindi fondamentale analizzare i segni grafici e le loro possibili articolazioni, per capire quali siano le condizioni che agevolano o che ostacolano l'interpretazione dello spazio rappresentato e poterli gestire opportunamente quando si vuole approdare a una comunicazione mirata. Se l'iter rappresentativo, ad esempio, è finalizzato a un'esperienza virtuale, questa consapevolezza è fondamentale per evitare insorgenza di malesseri indesiderati e riuscire a costruire un ponte comunicativo che riesca a veicolare i contenuti da trasmettere, anche quando la risposta sensoriale è alterata. Scopo del presente articolo è, pertanto, quello di analizzare gli stimoli forniti dagli indizi pittorici e, in particolare, interrogarsi su quale possa essere la risposta percettiva in condizioni di ambiguità visiva. La disamina si propone di indagare la raffigurazione pittorica come sorgente di quei codici figurativi che possono condurre a una piena lettura dello spazio e individuare quali azioni grafiche possano essere di supporto nella comprensione dell'ambiente rappresentato (come la VR), e quali, invece, compromettere la comunicazione visiva in caso di non neurotipicità.

a. S.Serlio, 1544 .

b. Spatial scheme

Fig. I. Schema spaziale (1554). Le fizio di Ser (1554). Le figure alla base della rappresentazione deviano dal rigore geometrico dell'immagine principale, ma vengono percepite in coerenza con la scena (elaborazione grafica Anna Lisa Pecora).
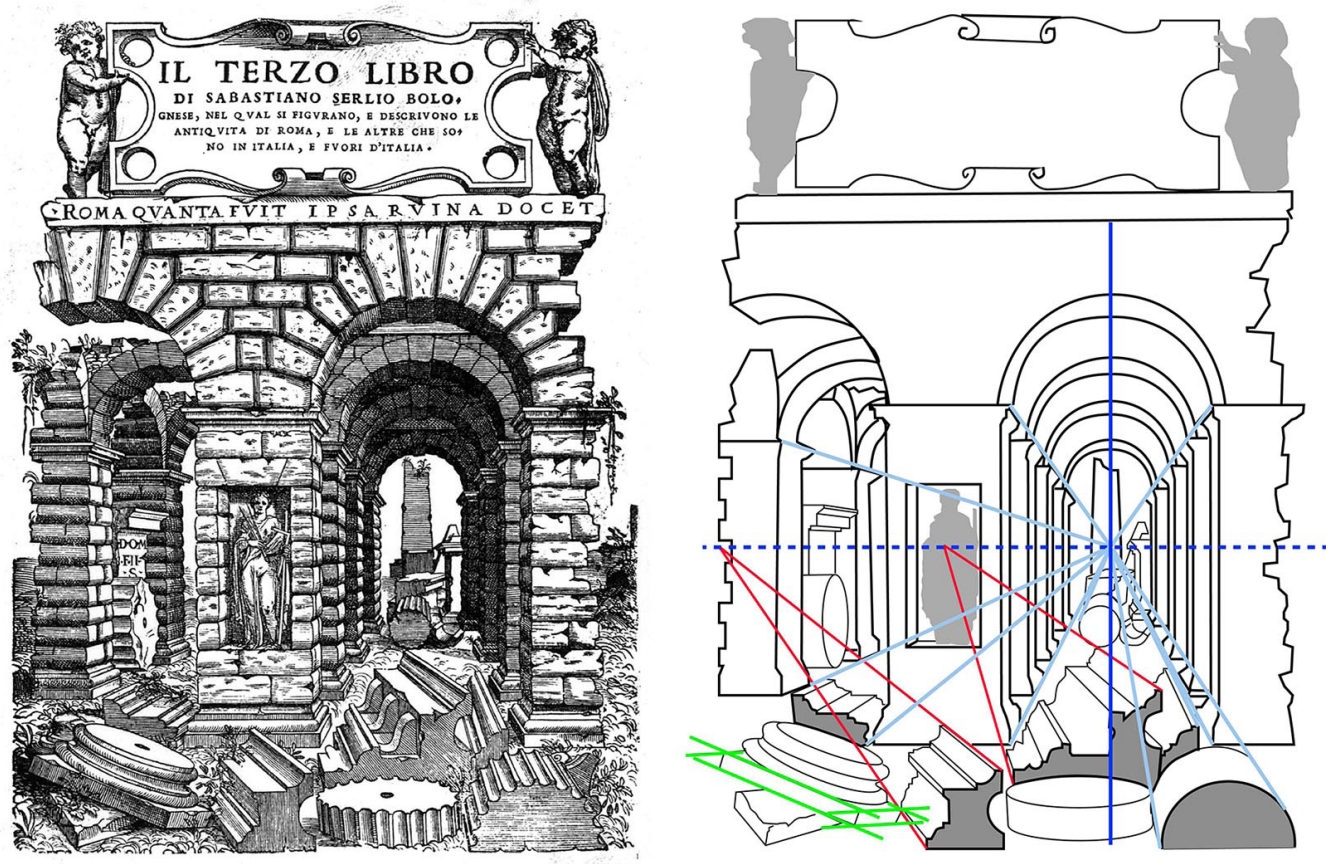

\section{L'importanza degli indizi pittorici nella lettura spaziale}

Quando si osserva un ambente virtuale, si osserva essenzialmente la rappresentazione di uno spazio, quindi, le informazioni non sono trasmesse direttamente dal contesto, ma da tracce che, in assenza di una decodifica, restano prive di alcun legame col modo fisico. L'interpretazione dell'operatore grafico, tuttavia, non è l'unica a incidere nel processo di comunicazione visiva attivato dall'immagine; a essa si sovrappongono fattori individuali di 
carattere fisiologico e psicologico che condizionano la percezione di una configurazione. La condizione psicologica, ad esempio, agisce creando un'aspettativa della sensazione futura e influenzando il soggetto al momento dell'osservazione. Tuttavia, se ciò è diffusamente verificato per condizioni neurotipiche, non sempre l'esperienza ha un ruolo in caso di atipicità percettiva [Bogdashina 20I5, p. 33], inducendo risposte inconsuete nell'interpretazione degli input visivi. Poiché l'immagine percepita dai sensi è pur sempre elaborata tramite un processo proiettivo sulla superficie della retina, alcuni input visivi elaborati dal cervello nel riconoscimento della profondità spaziale, sono associabili a quelli messi in campo nelle raffigurazioni pittoriche. Tra questi "indizi pittorici", la "prospettiva lineare" è forse il più coercitivo; essa fa sì che ciascun gradiente acquisisca un valore percettivo funzionale alla lettura della profondità. II "gradiente di dimensione", seppur gestito con diverse modalità, è uno dei più efficaci nel restituire un credibile effetto di profondità. Le raffigurazioni cinquecentesche ne supportano la forza coercitiva mettendo in atto un impalcato strutturale coerente, governato dalle regole prospettiche. Ad esempio, nel frontespizio del terzo libro di Serlio, la regolarità dei gradienti, rafforza la loro efficacia percettiva. Dimensioni e distanze si riducono con gradualità, rispettando anche gli allineamenti lungo le fughe prospettiche. In questo modo, figure disuguali vengono interpretate come la rappresentazione di oggetti uguali ma in progressivo allontanamento, trasformando l'obliquità dei segni grafici, in una configurazione più semplice, percepita prospetticamente. In una composizione così coerente, il sistema di indizi spaziali è talmente coercitivo da far sì che l'occhio trascuri eventuali irregolarità. I frammenti che si trovano alla base della raffigurazione deviano dal rigore geometrico che caratterizza il resto della rappresentazione e assumono punti di fuga arbitrari pur appartenendo a oggetti in posizione frontale. Tuttavia, le regole geometriche che governano le forme "anomale" non sono facilmente decifrabili e risultano prive di forza coercitiva. Lo sguardo, pertanto, accoglie il complesso figurativo come un insieme unitario e, in particolare, come spiega Arnheim: "I'ambiente ha la meglio e l'oggetto cede assumendo una deformazione" [Arnheim 1997, p. 237] (fig. I). Simili configurazioni spaziali, dove gli indizi di profondità sono dichiarati con forza espressiva e rimarcati da più gradienti, possono aiutare le persone autistiche nella lettura della spazialità in ambiente immersivo. I DSA, infatti, spesso evidenziano scarse capacità immaginative e diffusi problemi nella lettura della tridimensionalità.

Anche quando lo spazio appare frammentario e i suoi elementi non sono vincolati da un principio regolatore univoco, l'indizio di 'dimensione' o 'grandezza relativa' è efficace nel comunicare la sensazione di profondità. Osservando, ad esempio, un qualsiasi quadro impressionista come il celebre Les Coquelicots, di Monet (fig. 2), ci accorgiamo che basta il decrescere graduale delle pennellate rosse a restituire l'effetto della profondità spaziale, pur in totale assenza di contorni netti e di linee di fuga che guidino lo sguardo verso lo sfondamento del piano frontale. Lo stesso può dirsi osservando, nella Golconde di Magritte (fig. 3), le repliche dell'uomo con bombetta, reiterate con diverse dimensioni su tutta la superficie del quadro. Qui, l'insieme dei gradienti generati dal loro moltiplicarsi, genera lo spazio tridimensionale in cui tutto assume una collocazione, anche gli edifici. Comunemente, è in base all'esperienza che siamo in grado di mettere in relazione l'oggetto e il suo contesto, riuscendo a dare un giudizio, seppur sommario, delle posizioni spaziali e ricostruendo l'illusione di uno spazio prospettico. Per Beltrame, l'interpretazione di una configurazione prospettica come struttura tridimensionale non è scontata; vi si approda quando sussistano esperienze pregresse sulla volumetria e la grandezza delle forme rappresentate, in caso contrario, si può giungere

Fig. 2. Gradiente di dimensione nel dipinto di Monet Les Coquelicots (1873) (ela grafica Anna Lisa Pecora).
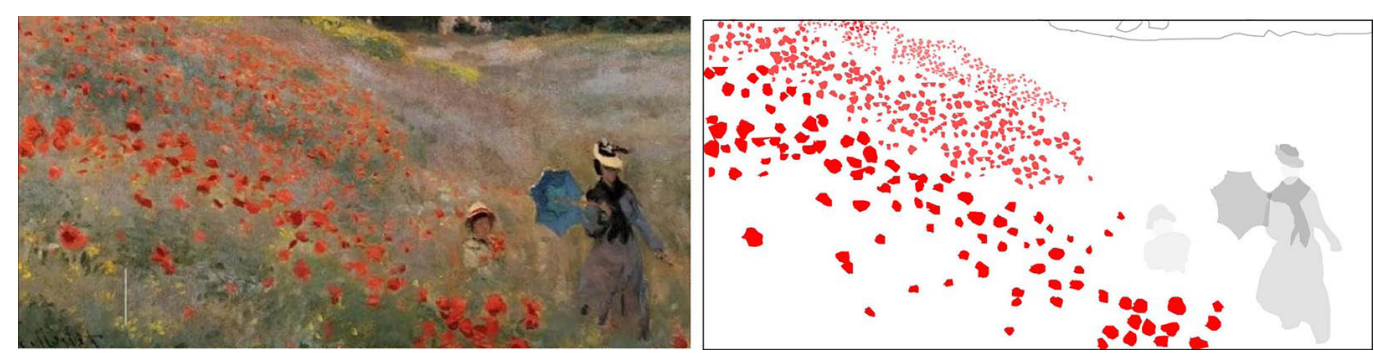
Fig. 3. Principio di costanza visiva nel dipinto di Magritte La Golconde (1953). Le figure simil reiterate con diverse dimensioni, costituiscono visivamente più piani di profondità (elaborazione grafica Anna Lisa Pecora) alla costruzione percettiva di una configurazione piana. Molti esperimenti sulle percezioni autistiche, ad esempio, registrano frequenti difficoltà nel creare, durante l'iter visivo, relazioni con le esperienze pregresse che agevolino l'attribuzione di significato e di riferimenti spaziali a ciò che si sta guardando [Brosnan et al. 2004, p. 46I]. Pertanto, anche in un ambiente virtuale, se i gradienti di deformazione e dimensione non vengono evidenziati con chiarezza (fig. 4), le informazioni sulle relazioni spaziali possono non essere elaborate: il 'sopra', 'vicino', 'davanti' non hanno significato in assenza di un confronto con le informazioni immagazzinate in passato [Bogdashina 2015, p. 56]. Inoltre, la lettura della profondità può essere complicata da comorbidità con problemi optometrici, come quelli di allineamento oculare, errori di rifrazione, acuità, capacità oculomotoria, stereopsi e strabismo [Simmons et al. 2009, p. 2707]. Queste complicazioni sarebbero causa di alcune deformazioni visive come la tendenza a misinterpretare gli indizi di profondità spaziale. Più volte, i ricercatori, parlano di una visione 'piana' o 'bidimensionale', dovuta probabilmente a problemi di stereopsi e che ha ripercussioni nelle relazioni spaziali oltre che interpersonali. Nella progettazione $V R$, quindi, è importante che l'ambiente dichiari i suoi confini in maniera nitida, in modo da costituire dei riferimenti spaziali che possano essere rassicuranti ed evitare sensazioni di disorientamento. Più semplici sono gli schemi delle strutture spaziali, più si aiuta l'utente DSA a costruire una propria idea dello spazio e della propria posizione al suo interno, agevolando in tal modo le condizioni di comfort che ne conseguono [Simmons et al. 2009, p. 2710].
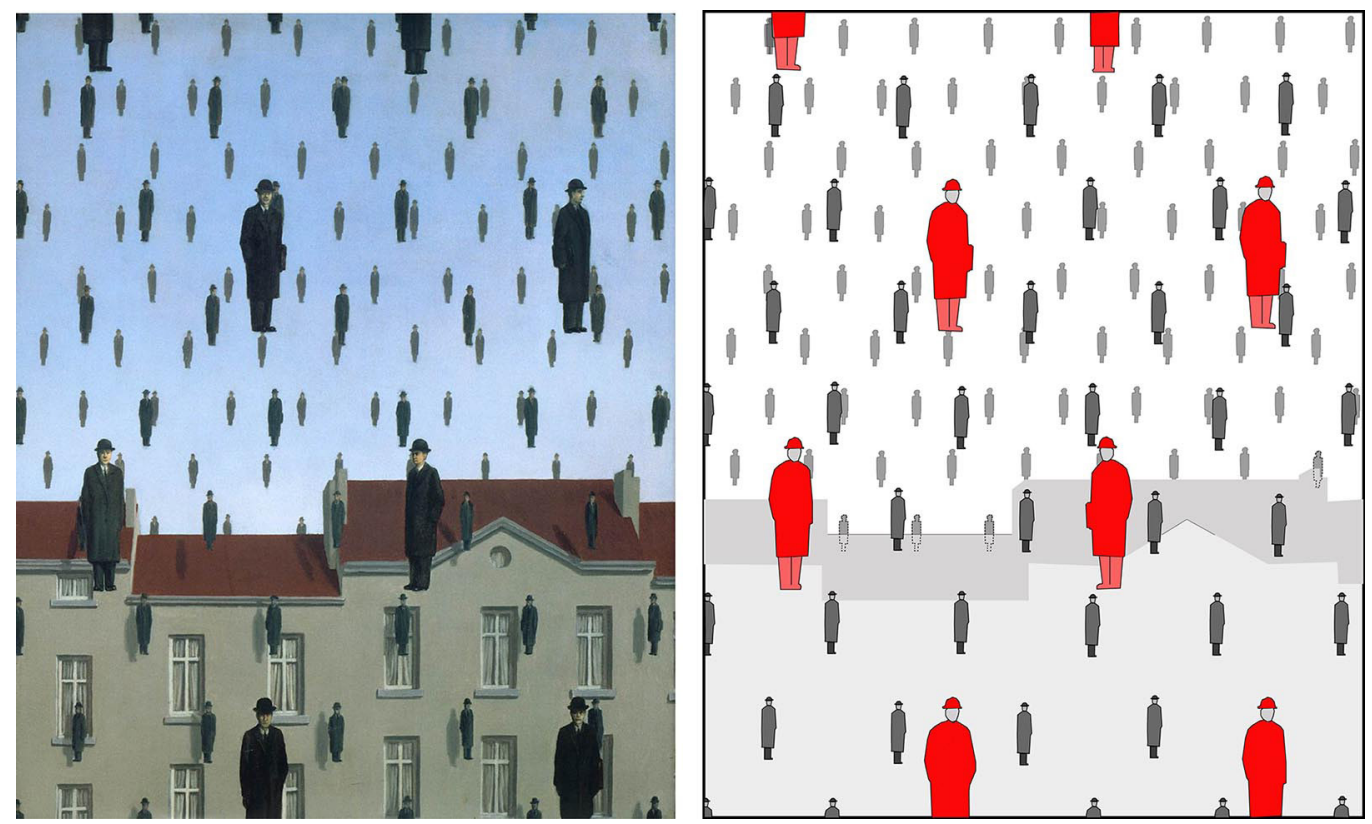

\section{Ambiguità dei segni e influenza del contesto}

Le problematiche DSA nell'interpretazione spaziale possono essere legate anche al fatto che le persone autistiche non sempre contano sulla memoria delle esperienze visive durante l'iter percettivo, il che li porterebbe a osservare il mondo, in ogni istante, come fosse la prima volta. Una conseguenza diretta del vedere tutto 'come è', e non come ci aspettiamo possa essere, è una 'percezione letterale', priva di interpretazioni personali o di condizionamenti preconcetti, pertanto è fondamentale che l'ambiente immersivo sia quanto più possibile riconoscibile, privo di soluzioni spaziali non riscontrabili nella realtà fisica, come spesso avviene negli ambienti di gioco.

Con Magritte l'uso degli indizi pittorici può trovarsi anche in una relazione drasticamente controversa, offrendo uno scenario ampio di casistiche, tali da poterle mettere in relazione 
Fig. 4. a) Esempio ripreso da Second Life, applicazion usata frequentemente in contesti DSA; b) indiz spaziali: deformazione, riduzione delle dimensioni, convergenza; c) graduale desaturazione degli oggetti dovuta alla prospettiva aerea: d) riferimenti [Arnheim 1997].
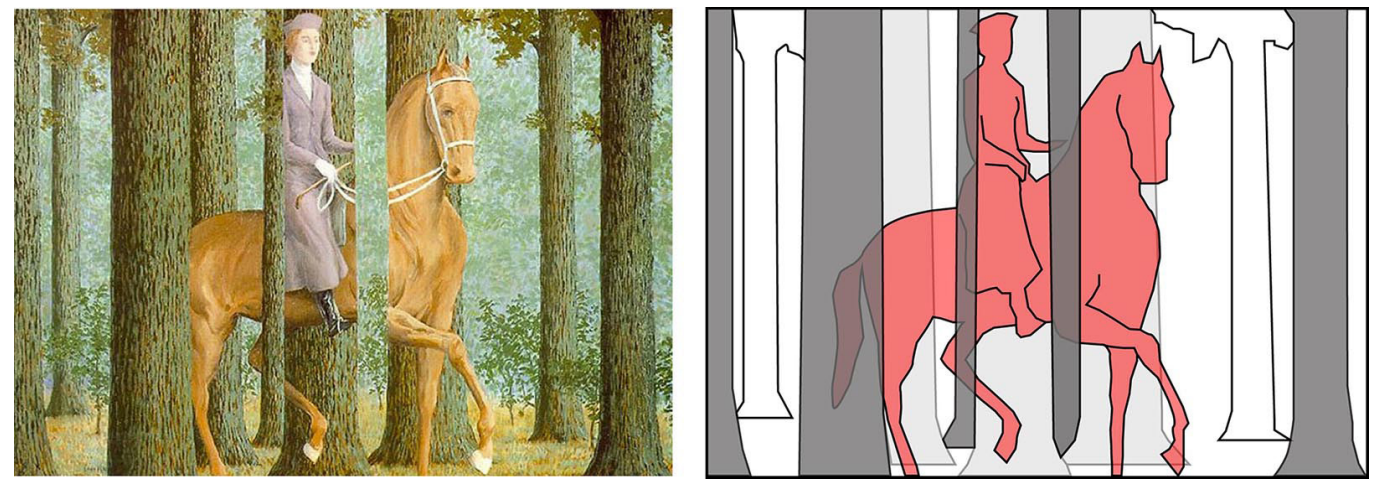

con risposte sensoriali atipiche. L'artista destreggia sapientemente tutti gli strumenti del linguaggio figurativo, utilizzando i principi della teoria Gestaltica, ma lo fa con un intento sovversivo: non per dare all'immagine pittorica sembianze familiari, quanto per trasfigurare la nostra immagine preconcetta del mondo, costruita con l'esperienza e che è all'origine delle nostre aspettative percettive [Taddio 201 I ]. Così Magritte libera la figurazione dalle sovrastrutture culturali che impediscono di osservare il segno grafico per quello che è, gestendo con perizia gli indizi di profondità per indurre uno choc visivo. Nel quadro Le blanc seing è emblematico l'uso ambiguo della relazione "figura-sfondo" e del criterio di "sovrapposizione". L'immagine della donna e del suo cavallo si alterna a quella del contesto alberato in una sorta d'intreccio visivo che rende impossibile un giudizio sulle reciproche posizioni spaziali. Vediamo la donna a cavallo celare porzioni dello sfondo che, contemporaneamente, in alcuni tratti, è spinto in avanti dall'illusione che copra a sua volta la coppia (fig. 5). L'ambiguità figurativa fa si che il comportamento 'amodale' si realizzi in entrambe le condizioni con una conseguente alternanza dei ruoli di figura e sfondo [I]. In condizioni di tipicità percettiva, l'osservatore non essendo in grado di trovare riferimenti noti per tale anomala l'alternanza figura-sfondo, giudica la configurazione priva di logica. Tuttavia, una persona autistica potrebbe pensarla diversamente. Oltre a una diffusa incapacità nell'autismo nel distinguere la
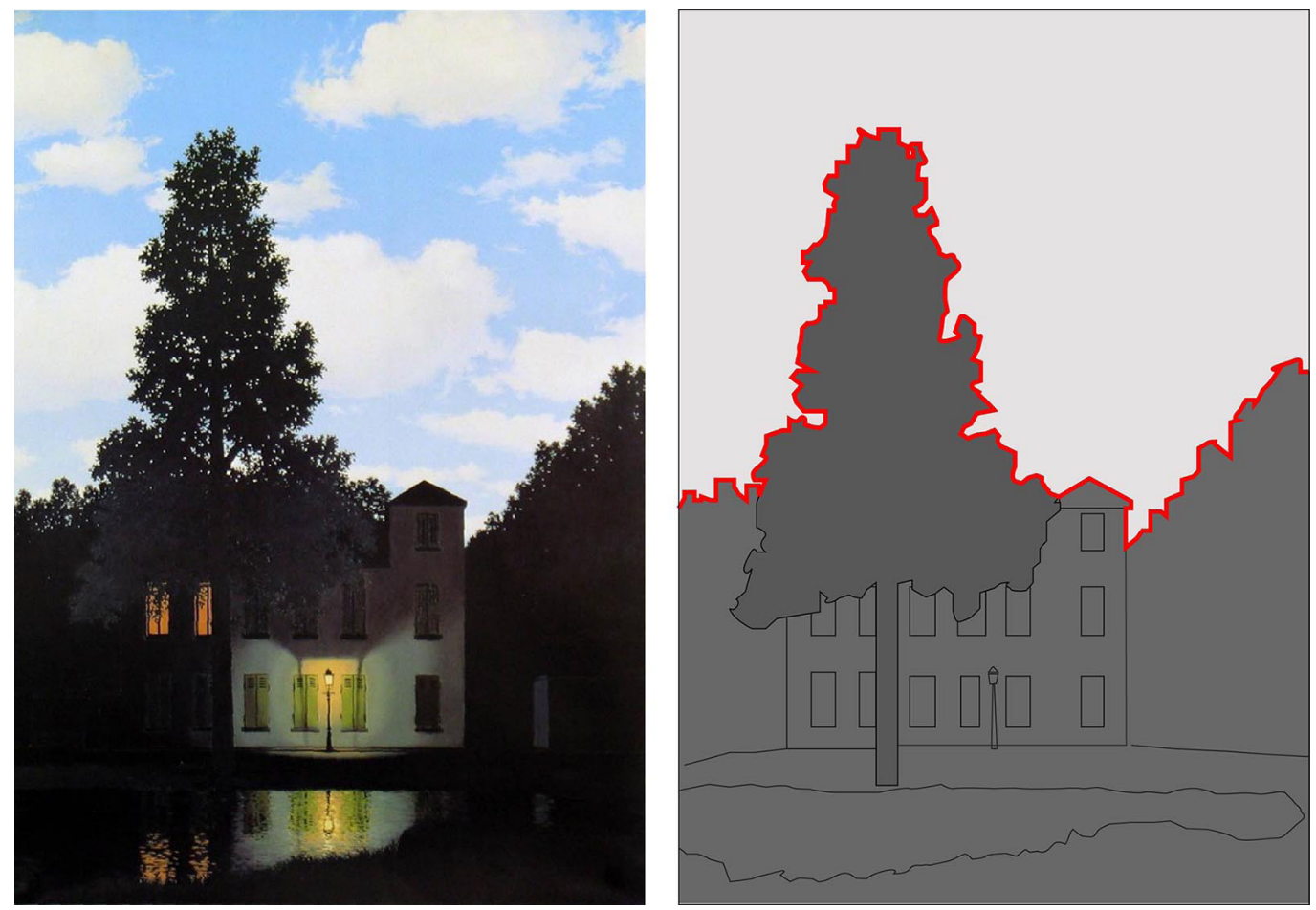
Fig. 6. Esempio d'immagine utilizzata da Brosnan Mark J. et al. per esperimenti sui processi gestaltici nell'autismo. figura dallo sfondo, si registrano frequenti difficoltà nel cercare e rintracciare relazioni tra le parti di una scena; ogni elemento, processato isolatamente a livello cognitivo, non assume un significato in relazione al confronto tra le parti. Dagli esperimenti svolti sulle percezioni DSA, si evince che, in alcuni casi, gli autistici non sembrerebbero subire l'influenza del contesto. Uno degli esperimenti più comuni su questo tema, è quello delle figure nascoste. In questo caso all'utente è chiesto di estrapolare una sagoma semplice da un complicato groviglio di linee (fig. 6) [Brosnan et al. 2004]. Solitamente, l'estrapolazione della figura è ostacolata dall'influenza del contesto che, con le sovrapposizioni di forme, costituisce un distrattore. Le persone autistiche, partecipanti agli esperimenti, non manifestano ingerenze da parte della struttura globale mostrandosi, anzi, i più rapidi nell'espletamento dell'esercizio [Dakin 2005]. Quindi, mentre le persone neurotipiche sono fortemente condizionate dal numero e dalla qualità delle caratteristiche che distinguono l'oggetto della ricerca dal contesto, non è così per gli autistici.

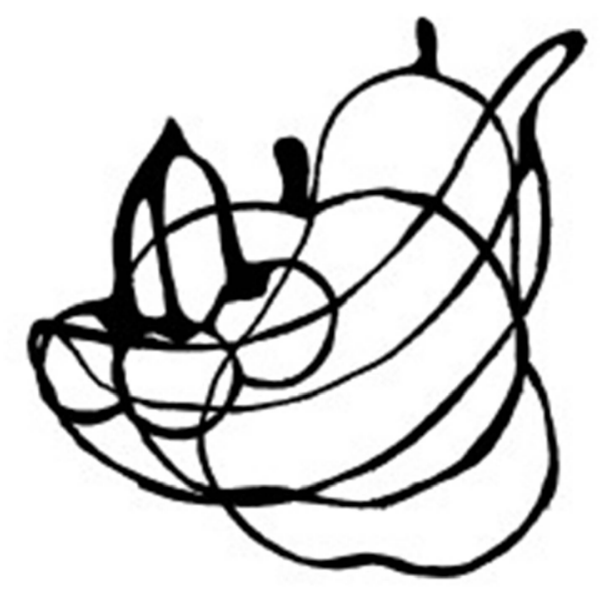

Continuando con Magritte, un altro esempio che pone al centro del dipinto il binomio figura-sfondo è Empire-lumieres (fig. 7), in cui è sempre dal confronto tra le parti della scena e dalla possibilità di metterle in relazione soggetto e contesto che la figurazione può essere giudicata surreale; cosicché il contatto visivo tra due condizioni opposte e distanti nel tempo ci appare impossibile.

II coraggioso esperimento magrittiano può sortire effetti inattesi qualora i sistemi percettivi di una persona non rispondano come di consueto. Mottron e Belleville, nel 1993, sostengono l'ipotesi che, nelle persone autistiche, le componenti 'locali' e 'globali' degli stimoli visivi non siano organizzate gerarchicamente come nel 'tipico' iter percettivo. Quindi, queste componenti vengono processate senza alcuna integrazione, a livello cognitivo, degli stimoli visivi [Courtney 2005 p. 64]. Anche la Weak Central Coherence Theory (WCC), sviluppata da Happè e Frith nel 2006, sostiene la mancanza di un'integrazione degli stimoli locali per approdare a un'entità globale. Secondo questo principio l'incapacità di filtrare le informazioni di fondo da quelle di primo piano sarebbe causata da una tendenza a ricevere tutti gli input sensoriali simultaneamente, con illimitato dettaglio e in modo olistico [Bogdashina 20 I 5, p. 55]. All'interno di una scena ambigua, pertanto, i dettagli, letti isolatamente, non assumono nessun significato, ma rimangono parti a sé stanti e, allo stesso tempo, in assenza di riferimenti esperienziali, l'ambiguità non viene interpretata come tale, ma semplicemente come caos visivo. Non costruendo relazioni di senso tra gli elementi di una configurazione, questa modalità percettiva può diventare insostenibile e generare un sovraffollamento sensoriale. In una progettazione di VR autism friendly, pertanto, è indispensabile eliminare dettagli superflui, che non siano funzionali alla lettura della configurazione spaziale. L'ambientazione virtuale deve avere una struttura semplice e a basso contenuto di informazioni; pochi colori, utili al riconoscimento di target e semplici texture, che agevolino l'orientamento, potranno agevolare il senso di confort e ridurre dolorose sollecitazioni sensoriali. 


\section{Conclusioni}

Se le regole elencate fin qui, hanno un valore nel guidare l'osservatore verso la spazialità della rappresentazione, ne consegue che la loro sovversione potrebbe generare esiti contrastanti o anche opposti alle aspettative, qualora fosse calata in un contesto non neurotipico. Nel caso di persone autistiche, ad esempio, nelle quali è frequente una 'percezione a tunnel', la tendenza a un'attenzione selettiva potrebbe causare una frammentazione della scena, con una compromissione anche totale della comunicazione spaziale. In alcuni casi, ciò può indurre una sensazione di insostenibile rumore visivo e di iperstimolazione sensoriale. Naturalmente, gli "indizi pittorici" non sono gli unici a condizionare l'iter di decodifica dello spazio rappresentato. Entrano in gioco anche caratteristiche fisiologiche e neurologiche, con un funzionamento non sempre identico per tutti [Jerald 2016, p. I2I]. La diversa risposta agli stimoli visivi implica, pertanto, un approfondimento che indaghi il nesso tra le percezioni atipiche e la lettura degli indizi spaziali. Solo in questo modo gli ambienti rappresentati per la comunicazione, potranno offrire una risposta inclusiva e adeguata alle esigenze di un pubblico più ampio possibile.

a

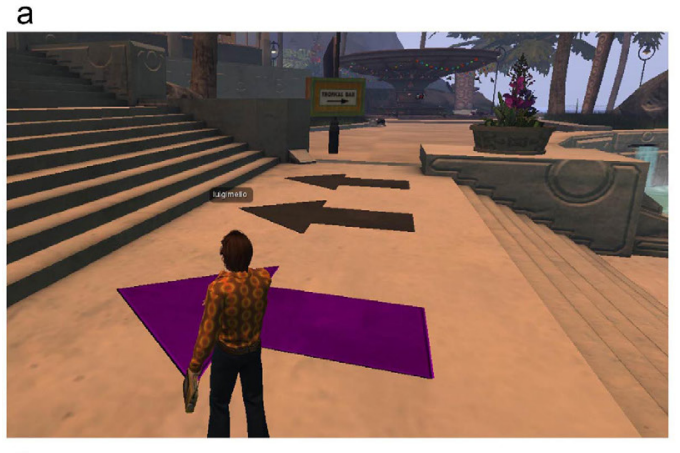

C

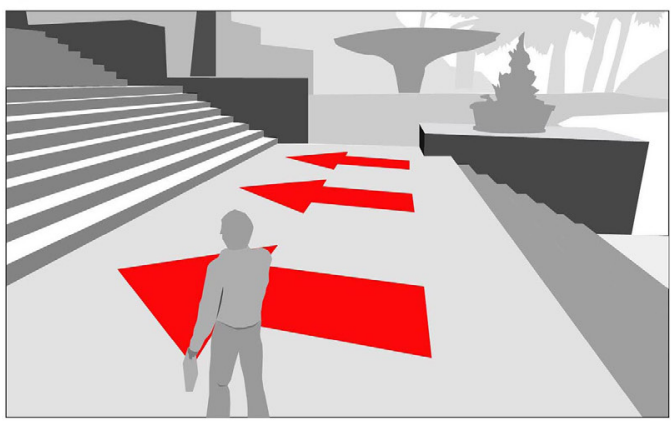

b

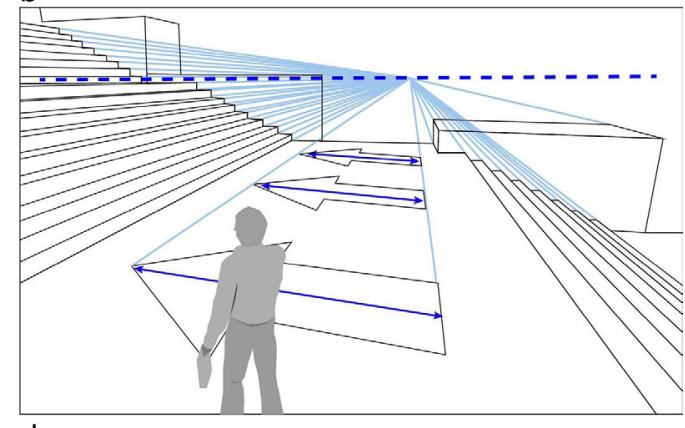

d

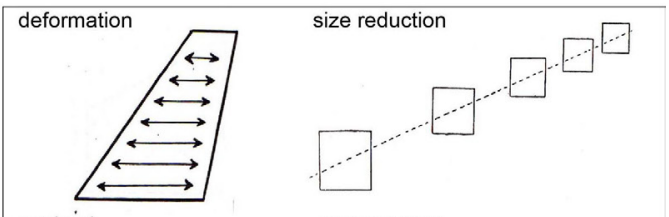

contrast

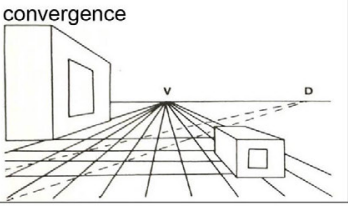

Note

[I] II completamento 'amodale' si verifica quando due immagini distinte appaiono come parti di un elemento unico, ma interrotto visivamente da un occludente.

\section{Riferimenti bibliografici}

Amoruso G. (a cura di). (20 I I). La ricerca nel disegno di design. Santarcangelo di Romagna (RN): Maggioli Editore.

Argenton A. (2017). Arte e cognizione. Introduzione alla psicologia dell'arte. Milano: Raffaello Cortina Editore.

Arnheim R. (1997). Arte e percezione visiva. Milano: Feltrinelli.

Attaianese E., Minucci G. (2019). Progettare percezione e piena fruizione dei siti di interesse culturale da parte di persone con autismo. In A.F.L. Baratta, C. Conti, V. Tatano (a cura di). Inclusive Living. II Design for an autonomousand independent living, pp. 302-3 I I. Conegliano: Anteferma Edizioni S.r.l..TV.

Baumers S., Heylighen A. (20 I0). Beyond the Designers' View: How People with Autism Experience Space. In David During (a cura di). International conference Design \& Complexity. Atti del DRS Conference 20 I0. Montreal (Quebec), Canada, 7-9 Luglio 20 I I, pp. I-9. Montréal: Design Research Society. 
Beltrame R. (1989). La percezione dello spazio tridimensionale: architettura e prospettiva. In Methodologia, 5, pp. I- I6.

Bogdashina O. (20I5). Le percezioni sensoriali nell'autismo e nella sindrome di Asperger.Vignate (MI): Uovonero.

Brosnan M. J. et al. (2004). Gestalt processing in autism: failure to process perceptual relationships and the implications for contextual understanding. In Journal of Child Psychology and Psychiatry, 45:3, pp. 459-469.

Carpenzano O. (2012). Idea immagine architettura. Tecniche d'invenzione architettonica e composizione. Roma: Gangemi Editore.

Courtney P. B. et al. (2005). Weak Central Coherence and Its Relations to Theory of Mind and Anxiety in Autism. In Journal of Autism and Developmental Disorders, vol. 35, n. I., pp. 63-73.

Dakin S., Frith U. (2005). Vagaries of Visual Perception in Autism. In Neuron, vol. 48. pp. 497-507.

De Rosa A. ( 1998). L'infinito svelato allo sguardo. Forme della rappresentazione estremo-orientale. Torino: Città studi edizioni.

Delacato C. H. (1974). The ultimate stranger, the autistic child. New York: Garden City, Doubleday.

Florio V. (2012). Sul disegno. Riflessioni sul disegno di architettura. Roma: Officina Edizioni.

Gorini A. et al. (2008). A second life for Health: prospects for the use of 3-D virtual worlds in clinical psychology. In Journal of medical Internet research, 10(3):e21, vol. I0.

Grandin T. (2007). Autism from the Inside. In Educational Leadership, 64, n. 5, pp. 29-32.

Guy J., Mottron L., Bertone A. (2019). A Developmental Perspective of Global and Local Visual Perception in Autism Spectrum Disorder. In J Autism Dev Disord, pp. 2706-2720. Springer.

Jason J. (2016). The RV Book: Human centered design for Virtual Reality. ACM Books \#8.

Katz D. (1992). La psicologia della forma. Torino: Bollati Boringhieri.

Marcolli A. (197I). Teoria del Campo I. Firenze: Sansoni.

Newbutt N. (2018). Using virtual reality with autistic pupils: information and advance. Milton Keynes: National Autistic Society.

Novello G., Lo Turco M. (2016). La tridimensionalità dell'Architettura e la sua rappresentazione: un ponte sospeso tra le interpretazioni dei trattatisti italiani del XVI secolo e le metodologie di elaborazione della contemporaneità. In El Arquitecto, de la tradiciòn al siglo XXI, tomo I, I3, pp. I24I- 1250.

Pagliano A. (20I I). Prospettive meravigliose: i paesaggi illusori di Giuseppe Galli da Bibiena. In Agribuisness Paesaggio \& Ambiente, vol. XVI, n. I, pp. 70-76.

Pellegatta C. (2019). Immagine o Disegno?. In P. Belardi (a cura di). Riflessioni. L'arte del disegnolil disegno dell'arte. Atti del 4 I Convegno Internazionale dei Docenti della Rappresentazione. Perugia 19-21 settembre 2019, pp. I83- I91. Roma: Gangemi Editore International.

Ravasio A. (20 I I). L'impiego dei sistemi di Realtà Virtuale in psicologia Clinica. In Scienze dell'interazione. Rivista di psicologia clinica e psicoterapia, n. I., vol. 3, pp. 47-69.

Realpe A. et al. (2019). Co designing a virtual world with people to deliver social cognition therapy in early psychosis. In Early intervention in Psychiatry, pp. 1-7.

Robertson C. E. et al. (2013). Tunnel Vision: Sharper Gradient of Spatial Attention in Autism. In The Journal of Neuroscience, 33(16), pp. 6776-6781.

Rossi D., Olivieri A. (2019). First Person Shot: la prospettiva dinamica interattiva negli ambienti virtuali immersivi. In P. Belardi (a cura di). Riflessioni. L'arte del disegnolil disegno dell'arte. Atti del 4 I Convegno Internazionale dei Docenti della Rappresentazione. Perugia 19-21 settembre 2019, pp. 977-984. Roma: Gangemi Editore International.

Sheppard E., Ropar D., Mitchell P. (2009). Perceiving the impossible: How individuals with autism copy paradoxical figures. In Autism, I3(4), pp. 435-452.

Simmons D.R. et al. (2009). Vision in autism spectrum disorders. In Vision Research, 49(22), pp. 2705-2739.

Smith D., Ropar D., Allen H. A. (2015). Visual integration in autism. In Human Neuroscience, 9:387.

Taddio L. (20II). Fare cose con i fenomeni. Immagini e percezione: Magritte e la natura delle rappresentazioni pittoriche. In Rivista di estetica, 48, pp. 175-201.

Autore

Anna Lisa Pecora, Università degli Studi di Napoli “Federico II", annalisa.pecora@iuna.it

Per citare questo capitolo: Pecora Anna Lisa (202I). Il linguaggio grafico e gli indizi pittorici per una comunicazione inclusiva dello spazio/Graphic language and pictorial clues for an inclusive communication of space. In Arena A., Arena M., Mediati D., Raffa P. (a cura di). Connettere. Un disegno per annodare e tessere. Linguaggi Distanze Tecnologie. Atti del $42^{\circ}$ Convegno Internazionale dei Docenti delle Discipline della Rappresentazione/ Connecting. Drawing for weaving relationship. Languages Distances Technologies. Proceedings of the $42^{\text {th }}$ International Conference of Representation Disciplines Teachers. Milano: FrancoAngeli, pp. 963-978. 


\title{
Graphic Language and Pictorial Clues for an Inclusive Communication of Space
}

\author{
Anna Lisa Pecora
}

Abstract

Currently, the increase of virtual tours is also stimulated by health emergence. The topic of the new media for the spreading of the heritage focuses on the representation disciplines; they can provide a useful guide for the figurative language in order to reach a powerful and universal communication. Any virtual, augmented or immersive experience involves a representative process with an interpretation and a codification of spatial information in graphic signs. Such a process requires a deep knowledge of drawing expressive codes in order to well manage the information that has to be turned into graphics and to empower communication. However, sometimes technology and sensationalism become priorities at the expense of human factors. A superficial or wrong design of graphic apparatus in virtual reality (VR) system, could provide sickness and affect the narrative values of communication. The aim of the present paper is to analyze in detail some pictorial codes, basic for the understanding of the space, in order to provide a wide reading of spatial cues over the common interpretation of typical development. This way it will be possible to take into count several aspects useful to extend the use of the virtual environment to people with atypical sensorial answers.

Keywords

representation, Pictorial Cues, Autism (ASD), Spatial Communication.
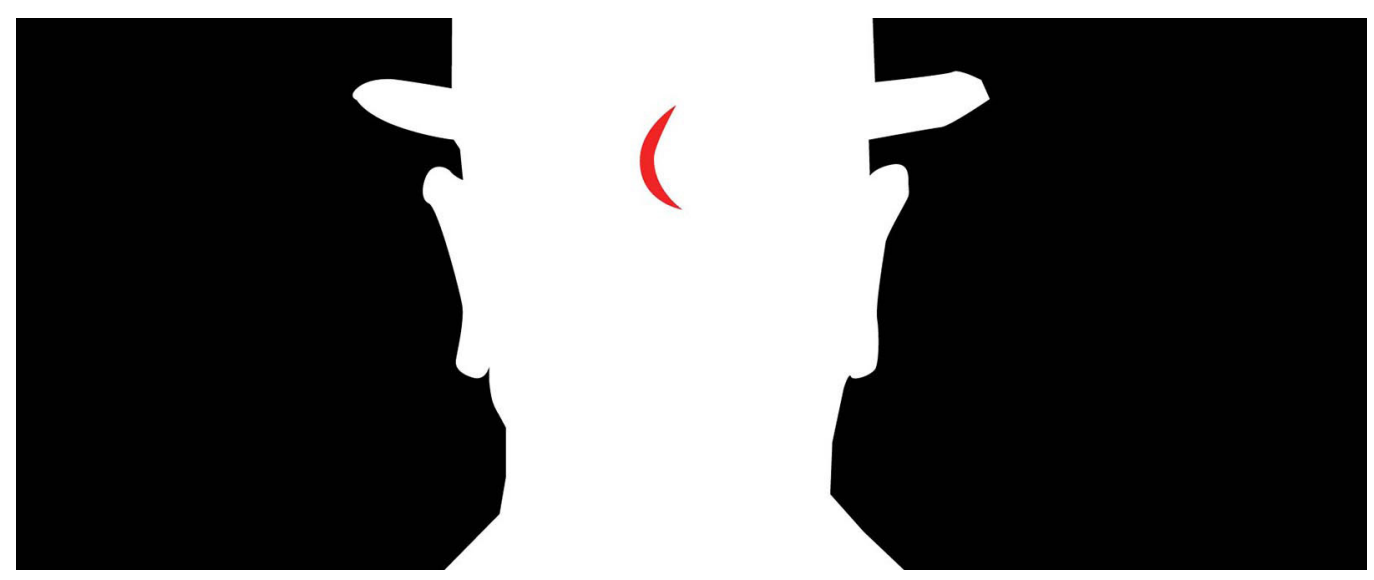


\section{Introdution}

An image (drawing, photo or render) always involves an interpretation process that overlaps our visual procedure. Over the individual differences, usually, in the typical development people, the mind simplifies the information depending on mental categories and experiences in order to read a global figurative pattern. The visual "agnosia", frequently observed in autism, this ability can affect. Usually, agnosia causes a tendency to focus on details which can lead to a bias in perceptual Gestalt processes. Therefore it's essential to analyze the graphic signs and their layout in order to understand the conditions helping or preventing the interpretation of represented space; this way it will be possible to well manage them to reach a targeted communication. For example, if the representative process is aimed at a virtual experience, the knowledge of the right design strategy is important to avoiding sickness but, especially, to build a communicative bridge, able to transfer meaning also when the sensorial answer is impaired. So, the aim of the present paper is to analyze the stimuli provided by pictorial cues and, in detail, analyzing the perceptual answer for visual ambiguity conditions. The discussion purpose investigating the pictorial representation as figurative codes source able to provide a whole spatial reading. This way it will be possible to define the right graphic design supporting or preventing the understanding of the drawn environment (as VR) in the case of non-neurotypical people.

a. S.Serlio, 1544.

b. Spatial scheme
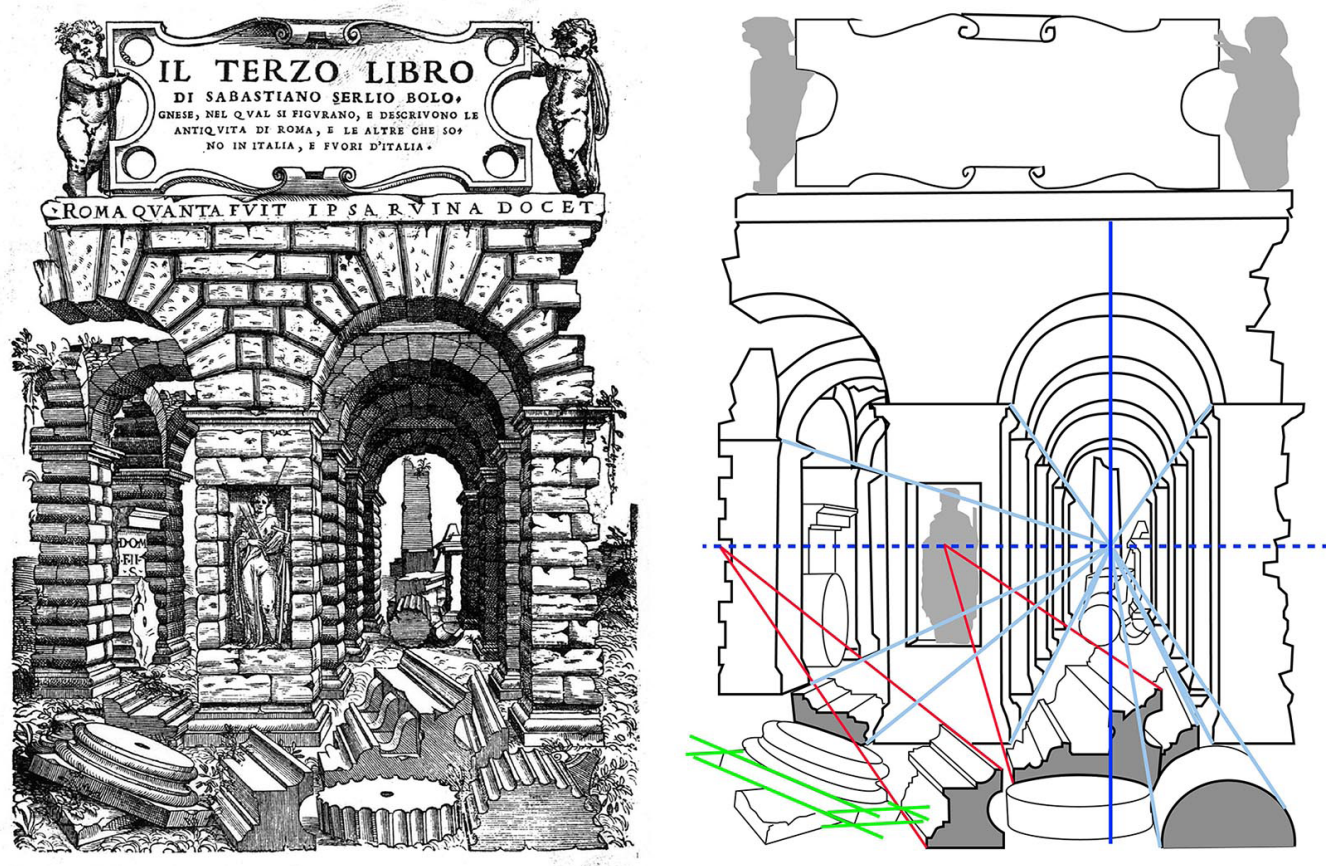

The importance of pictorial cues in the spatial reading

When we watch a virtual environment we essentially observe a drawn space, therefore, the information is not conveyed directly by the environment, but by graphic traces unlinked with the physical world if the right translation doesn't occur. However, in addition to the designer's interpretation, there are other aspects influencing the visual communication process activated by the image: personal physiological and psychological aspects 
interfere with the layout perception. The psychological condition, for example, creates an expectation of the future sensation, influencing the subject while sighting. However, this assumption is true for neurotypical development while in atypical perception the low influence of previous experience [Bogdashina 20I5, p. 33] could lead to bias in visual inputs interpretation. The "linear perspective" is one of the most compelling "pictorial cues"; it enhances the perceptual gradients in helping the perception of depth. The Renaissance paintings support their coercive force with the coherence of their graphic layout, managed by the perspective rules. For example, in Serlio's third book frontispiece, the gradients' regularity enhance their perceptual effectiveness. Dimensions and distances gradually decrease, following the alignments toward the vanishing points. So, different shapes are interpreted as the representation of similar objects moving away, turning the obliquity of graphic signs into a simpler perspective configuration. Here, the fragments on the bottom divert from the geometric representation rigor and they convey towards different vanishing points even if they belong to objects in the frontal position. Nevertheless, the geometry ruling the 'ambiguous' shapes is not easy to understand resulting without coercive force. So, the observer interprets the configuration as a uniform ensemble and, as Arnheim asserts: "the environment has the best and the object falls assuming a deformation" [Arnheim 1997, p. 237] (fig. I). Such spatial configurations, where depth clues are stated with expressive force and underlined by multiple gradients, can help autistic people to read spatiality in an immersive environment. DSAs, in fact, often show poor imaginative abilities and widespread problems in the reading of three-dimensionality.

Even if the space is fragmented and its elements are not linked by a single rule, the 'dimension' or 'relative size' cue is effective in communicating depth sensation. Watching an impressionist painting like Monet's Les Coquelicots, (fig. 2), the red decreasing of brushstrokes is enough compelling in communicating the spatial depth effect, even if there aren't defined contours or vanishing lines as a guideline for the sight. We have the same effect watching Magritte's painting the Colconde (fig. 3) thanks to the repetition, in different sizes, of the man with the bowler hat. Here, the multiple copies of the same shape set several kinds of gradients providing the image of a tridimensional space where each thing has a location. Commonly, we can compare the object with its context through experience, giving a personal summary opinion about spatial locations and therefore having the illusion of perspective space. In Beltrame's opinion, the interpretation of a perspective as a tridimensional space is not given: we see a perspective configuration when previous experiences give us information about the volume of the represented shape, without this knowledge we could see a planar image. Many studies about autistic perception report difficulties, while seeing, in creating links with previous experience; this lacking complicates the creation of relations among the observed object, its meaning and the surrounding space [Brosnan et al. 2004, p. 46 I]. Therefore, even in a virtual environment, if deformation and dimension gradients are not clearly highlighted (fig. 4), some problems can occur in processing information about spatial reference: "up", "near", "in front" have not meant without the reference with the past experience [Bogdashina 20 I5, p. 56]. Moreover, the reading of depth could be complicated by comorbidity with optometric problems as ocular alignment, refractive error, visual acuity, oculomotor capacity, stereopsis and strabismus [Simmons et al. 2009, p. 2707]. This impairment could lead to some

Fig. 2. Size gradient in the painting by Monet Les Coquelicots (1873), (graphic elaboration Anna Lisa Pecora).
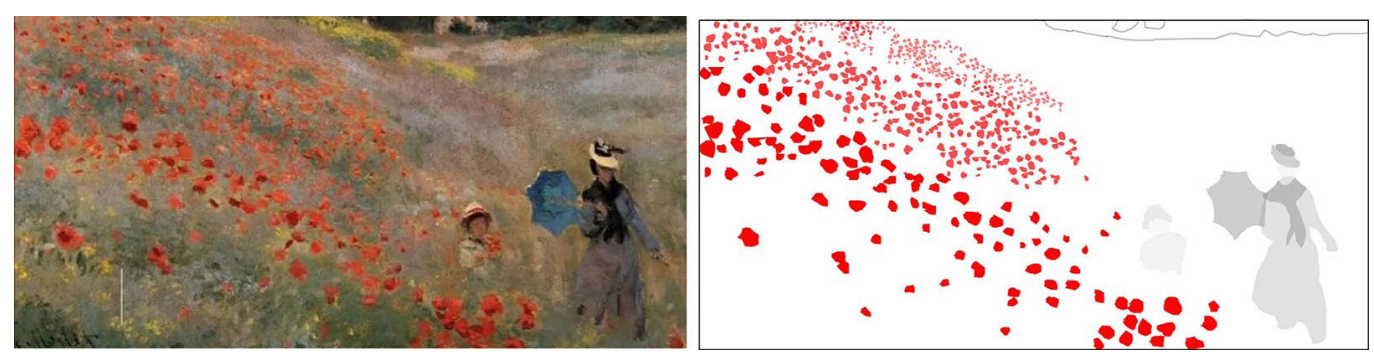
visual biases like difficulty in reading depth. Sometimes researchers describe stereopsis as a planar vision with consequences in personal and spatial relationships. Therefore, the virtual space should clearly declare its borders, this way giving spatial references that can provide reassuring conditions preventing confusion. The more the spatial layout is simple, the more the ASD user is helped to build his own idea about the space and his position in it, so enhancing comfort sensations [Simmons et al. 2009, p. 27I0].

\section{Signs ambiguity and the influence of the context}

ASD people don't use previous experiences while their perceptive process; so they observe the world each time like the first time. The direct consequence is a literal perception' without personal interpretation or preconceptions. Ropar and Mitchell find some perceptual answer in contradiction with the shape 'constancy' law, deducing that the acquired knowledge doesn't influence the visual judgment of autistic people, therefore, the immersive environment should be familiar, without unreal spatial solutions, frequently used for the gaming world.

Fig. 3. Principle of visual constancy in the painting by Magritte La Golcond (1953). Similar figures, dimensions, visually constitute multiple levels constitute (graphic elaboortion Anna Lisa Pecora).
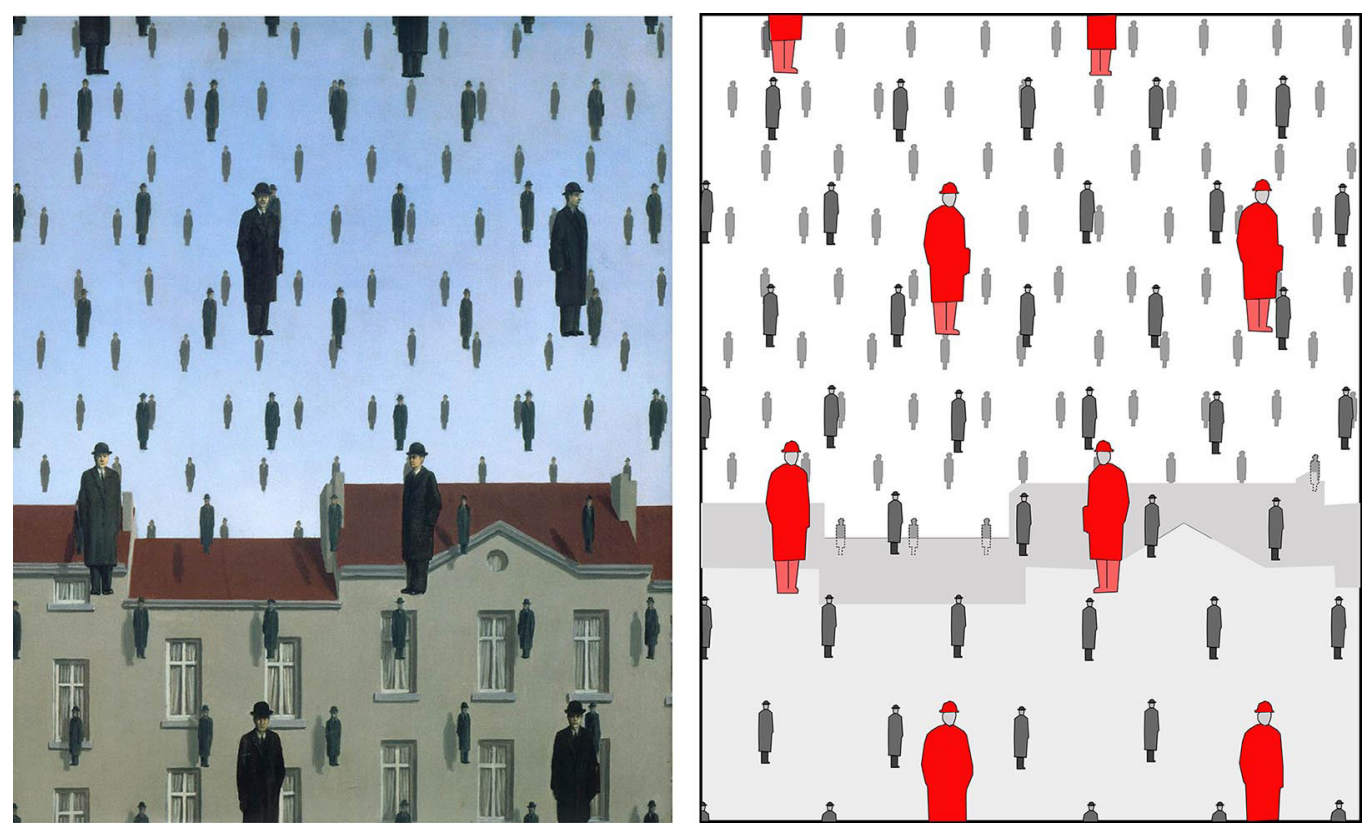

Magritte uses the pictorial cues also in an ambiguous relation, providing a wide range of examples that we can compare with atypical sensorial answers. The artist expertly manages the figurative language tools using Gestalt principles with a subversive aim: his aim is not to provide familiar pictures, but to turn our predetermined image of the world, where the experience influences our expectations [Taddio 20II]. Magritte removes from the representation the cultural constraints influencing our judgment to allow us observing the graphic sign as it is; he manages the depth cues with the ability to provide a visual choc. In the painting Le blanc seeing, he ambiguously uses the relation 'figure-ground' and the 'overlap' principle. The woman and her horse images take turns with the wooded environment setting a visual interweaving where it's impossible to recognize the mutual spatial locations. The woman on the horse hides the background as well as, somewhere, the ground moves in front, hiding the couple (fig. 5). So that the 
Fig. 4. a) Frame from Second Life, frequently used with ASD; b) spatial clues: deformation, size reduction, convergence; c) aerial perspective: the objects become more blurred and desaturated while moving away;

d) reference [Arnheim 1997].
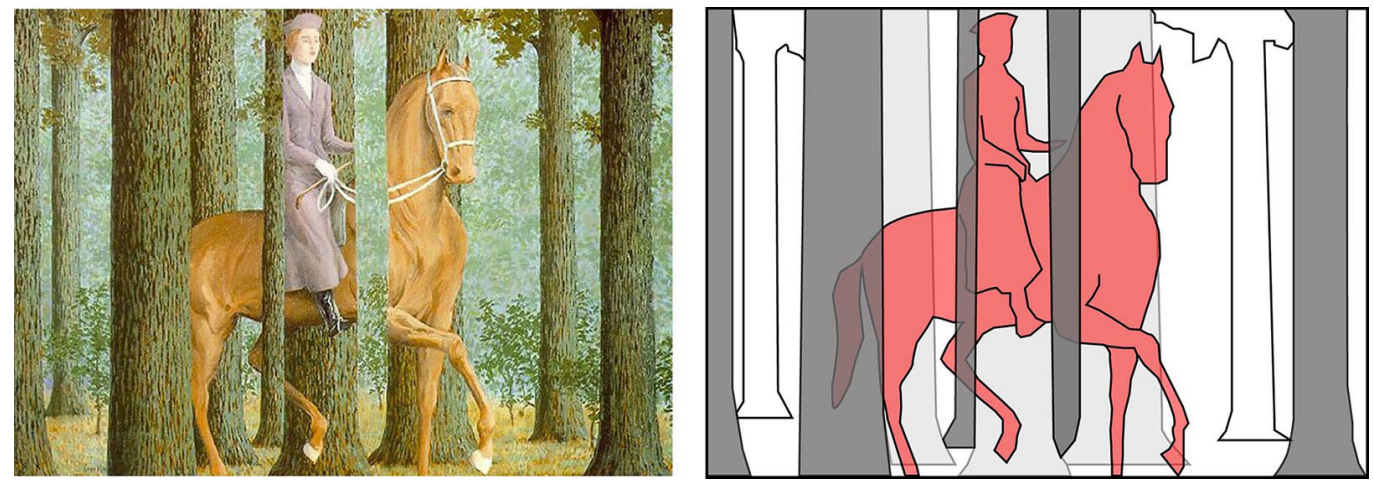

'amodal' behavior is realized in both conditions turning the roles figure-ground [I]. In a neurotypical condition, the observer is not able to find known references for the relation figure-ground and, therefore, he considers it illogic. However, an autistic person may think otherwise. In addition to a widespread inability in autism to distinguish the figure from the background, there are frequent difficulties in seeking and tracing relationships between the parts of a scene; each element, processed in isolation on a cognitive level, does not assume meaning if related to the different parts of the scene. The experiments on DSA perceptions report that, sometimes, autistics are not influenced by the context. The hidden figures are some of the most common experiments on this topic. In this case, the user is asked to extrapolate a simple shape from a complicated tangle of lines (fig. 6) [Brosnan et al. 2004]. Usually, the extrapolation of the figure is hindered by the influence of the context which, with the overlapping of shapes, constitutes a distractor. Autistic people, participating in the experiments, do not show interference from the global structure, showing, on the contrary, the fastest in performing the exercise [Dakin
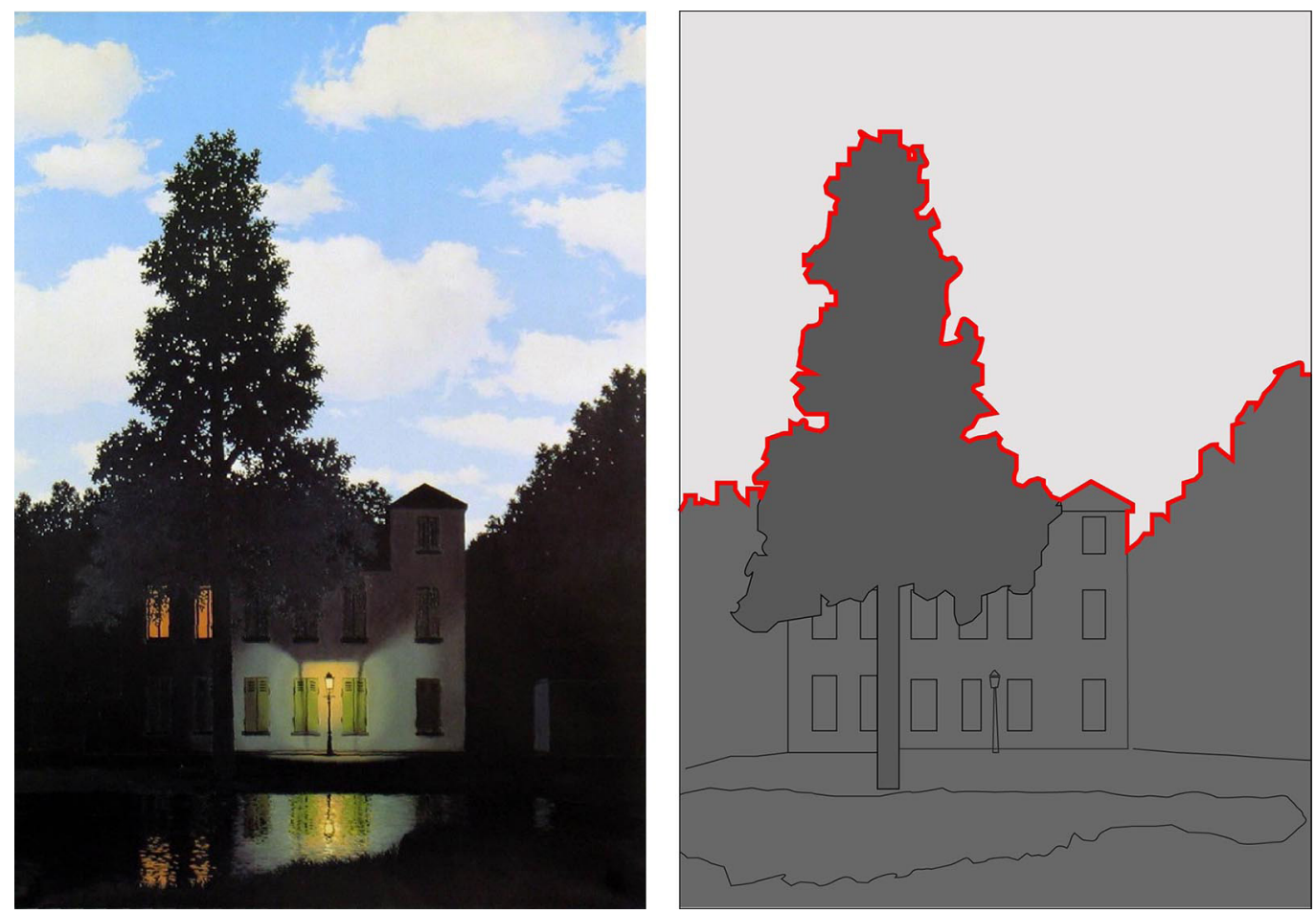

Fig. 5. Figure-ground relationship in the painting by Magritte Le Blanc Seign (1965), (graphic Pecora). 
2005]. Therefore, while neurotypical people are strongly conditioned by the number and quality of the context's objects, this is not the case for autistics.

Continuing with Magritte, another example that places the figure-background binomial at the center of the painting is Empire-lumieres (fig. 7). Here the picture usually appears surreal because of the comparison between the different elements of the scene; so that the visual contact between two opposite and distant conditions in time seems impossible to us.

However, Magritte's experiment could provide unusual effects if perceptual systems are impaired.

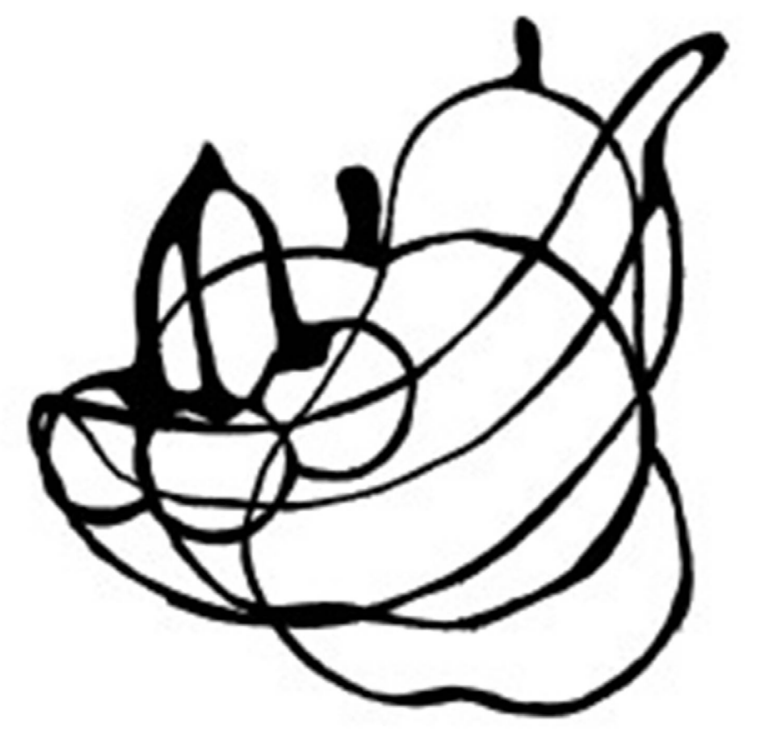

Mottron and Belleville, in 1993, claim that, in autistic people, the global and local components of perceptual stimuli are not hierarchically organized as in a typical development perceptive system. Therefore, such components are processed separately without brain integration of visual stimuli [Courtney 2005 p. 64]. Also, the Weak Central Coherence Theory (WCC), developed by Happè and Frith in 2006, argues the lack of local stimuli integration to reach a global entity. It asserts that the difficulty to select the ground information among the main information occurs because all the sensorial stimuli are kept simultaneously with unlimited detail and in a holistic way [Bogdashina 20 I 5, p. 55]. Inside an ambiguous scene the details, read separated, don't assume a meaning, but they are seen as autonomous parts. Without experience reference about them, the ambiguity, not caught, turns in visual confusion. Without meaning relations among the configuration elements, this perceptual modality can become unsustainable and provide sensorial overcrowding.

In an autism-friendly VR design, therefore, it is essential to eliminate superfluous details, which are not functional to the reading of the spatial configuration. The virtual setting should have a simple structure with low information content; few colors, useful for target recognition and simple textures, which facilitate orientation, will facilitate the sense of comfort and reduce painful sensory stresses. 


\section{Conclusions}

If the described rules are important in driving the user toward the represented spatiality, their overthrow could lead to opposite results in a non-neurotypical context. For example, autistic people, because of their "tunnel perception", could be fascinated by minimal detail, perceiving a fragmented scene, biasing the whole spatial communication. Sometimes it could provide painful visual noise and sensorial overstimulation. Sure, pictorial cues are not the only ones to influence the translation of the represented space. Also, the physiological and psychological aspects play a basic role with different characteristics for each one [Jerald 2016, p. 12I]. The different answer to visual stimuli needs a deep investigation about the relation between the atypical perceptions and the reading of spatial cues. Only this way the drawn spaces for communication could offer an inclusive answer for all.

a

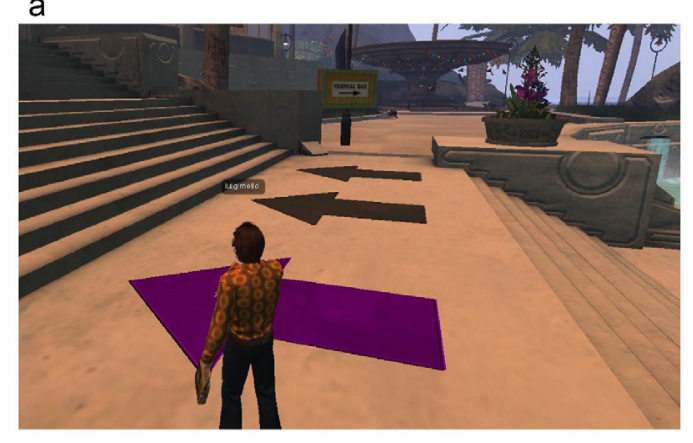

C

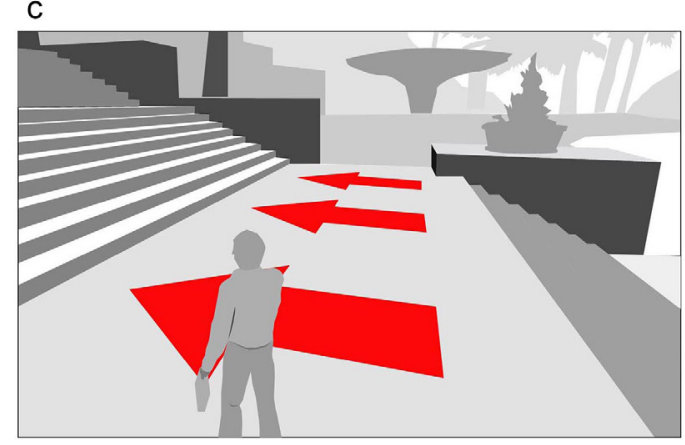

b

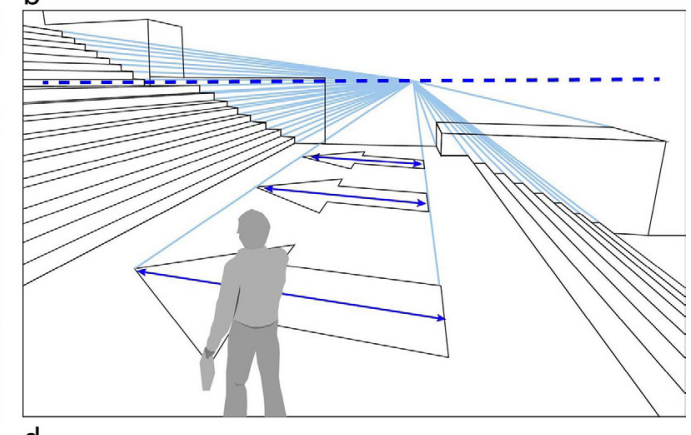

d

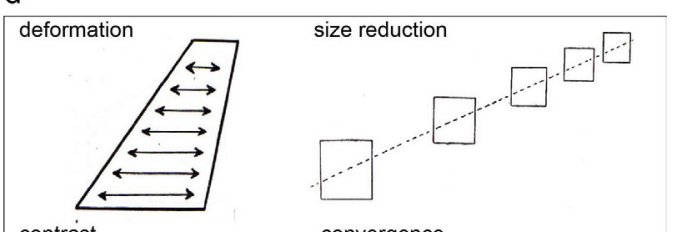

contrast

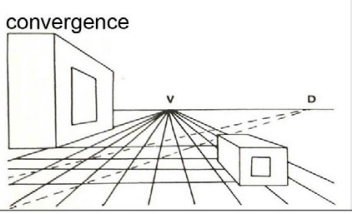

Notes

[I] The 'amodal' behavior occurs when two separated images appear as they are part of the same element interrupted by an overlapping.

\section{References}

Amoruso G. (a cura di). (20 I I). La ricerca nel disegno di design. Santarcangelo di Romagna (RN): Maggioli Editore.

Argenton A. (2017). Arte e cognizione. Introduzione alla psicologia dell'arte. Milano: Raffaello Cortina Editore.

Arnheim R. (1997). Arte e percezione visiva. Milano: Feltrinelli.

Attaianese E., Minucci G. (2019). Progettare percezione e piena fruizione dei siti di interesse culturale da parte di persone con autismo. In A.F.L. Baratta, C. Conti,V.Tatano (a cura di). Inclusive Living. II Design for an autonomousand independent living, pp. 302-3 I I. Conegliano: Anteferma Edizioni S.r.l.. TV.

Baumers S., Heylighen A. (2010). Beyond the Designers' View: How People with Autism Experience Space. In David During (a cura di). International conference Design \& Complexity. Atti del DRS Conference 20 I0. Montreal (Quebec), Canada, 7-9 Luglio 20 I I. pp. I-9. Montréal: Design Research Society. 
Beltrame R. (1989). La percezione dello spazio tridimensionale: architettura e prospettiva. In Methodologia, 5, pp. I- I6.

Bogdashina O. (20I5). Le percezioni sensoriali nell'autismo e nella sindrome di Asperger.Vignate (MI): Uovonero.

Brosnan M. J. et al. (2004). Gestalt processing in autism: failure to process perceptual relationships and the implications for contextual understanding. In Journal of Child Psychology and Psychiatry, 45:3, pp. 459-469.

Carpenzano O. (2012). Idea immagine architettura. Tecniche d'invenzione architettonica e composizione. Roma: Gangemi Editore.

Courtney P. B. et al. (2005). Weak Central Coherence and Its Relations to Theory of Mind and Anxiety in Autism. In Journal of Autism and Developmental Disorders, vol. 35, n. I., pp. 63-73.

Dakin S., Frith U. (2005). Vagaries of Visual Perception in Autism. In Neuron, vol. 48. pp. 497-507.

De Rosa A. ( 1998). L'infinito svelato allo sguardo. Forme della rappresentazione estremo-orientale. Torino: Città studi edizioni.

Delacato C. H. (1974). The ultimate stranger, the autistic child. New York: Garden City, Doubleday.

Florio V. (2012). Sul disegno. Riflessioni sul disegno di architettura. Roma: Officina Edizioni.

Gorini A. et al. (2008). A second life for Health: prospects for the use of 3-D virtual worlds in clinical psychology. In Journal of medical Internet research, 10(3):e21, vol. I0.

Grandin T. (2007). Autism from the Inside. In Educational Leadership, 64, n. 5, pp. 29-32.

Guy J., Mottron L., Bertone A. (2019). A Developmental Perspective of Global and Local Visual Perception in Autism Spectrum Disorder. In J Autism Dev Disord, pp. 2706-2720. Springer.

Jason J. (2016). The RV Book: Human centered design for Virtual Reality. ACM Books \#8.

Katz D. (1992). La psicologia della forma. Torino: Bollati Boringhieri.

Marcolli A. (197I). Teoria del Campo I. Firenze: Sansoni.

Newbutt N. (2018). Using virtual reality with autistic pupils: information and advance. Milton Keynes: National Autistic Society.

Novello G., Lo Turco M. (2016). La tridimensionalità dell'Architettura e la sua rappresentazione: un ponte sospeso tra le interpretazioni dei trattatisti italiani del XVI secolo e le metodologie di elaborazione della contemporaneità. In El Arquitecto, de la tradiciòn al siglo XXI, tomo I, I3, pp. I24I - 1250.

Pagliano A. (20I I). Prospettive meravigliose: i paesaggi illusori di Giuseppe Galli da Bibiena. In Agribuisness Paesaggio \& Ambiente, vol. XVI, n. I, pp. 70-76.

Pellegatta C. (2019). Immagine o Disegno?. In P. Belardi (a cura di). Riflessioni. L'arte del disegnolil disegno dell'arte. Atti del 4 I Convegno Internazionale dei Docenti della Rappresentazione. Perugia 19-21 settembre 2019, pp. I83- I91. Roma: Gangemi Editore International.

Ravasio A. (20 I I). L'impiego dei sistemi di Realtà Virtuale in psicologia Clinica. In Scienze dell'interazione. Rivista di psicologia clinica e psicoterapia, n. I., vol. 3, pp. 47-69.

Realpe A. et al. (2019). Co designing a virtual world with people to deliver social cognition therapy in early psychosis. In Early intervention in Psychiatry, pp. 1-7.

Robertson C. E. et al. (2013). Tunnel Vision: Sharper Gradient of Spatial Attention in Autism. In The Journal of Neuroscience, 33(16), pp. 6776-6781.

Rossi D., Olivieri A. (2019). First Person Shot: la prospettiva dinamica interattiva negli ambienti virtuali immersivi. In P. Belardi (a cura di). Riflessioni. L'arte del disegnolil disegno dell'arte. Atti del 4 I Convegno Internazionale dei Docenti della Rappresentazione. Perugia 19-21 settembre 2019, pp. 977-984. Roma: Gangemi Editore International.

Sheppard E., Ropar D., Mitchell P. (2009). Perceiving the impossible: How individuals with autism copy paradoxical figures. In Autism, I3(4), pp. 435-452.

Simmons D.R. et al. (2009). Vision in autism spectrum disorders. In Vision Research, 49(22), pp. 2705-2739.

Smith D., Ropar D., Allen H. A. (2015). Visual integration in autism. In Human Neuroscience, 9:387.

Taddio L. (20II). Fare cose con i fenomeni. Immagini e percezione: Magritte e la natura delle rappresentazioni pittoriche. In Rivista di estetica, 48, pp. I75-201.

Author

Anna Lisa Pecora, Università degli Studi di Napoli “Federico II", annalisa.pecora@iuna.it

To cite this chapter. Pecora Anna Lisa (202I). Il linguaggio grafico e gli indizi pittorici per una comunicazione inclusiva dello spazio/Graphic language and pictorial clues for an inclusive communication of space. In Arena A., Arena M., Mediati D., Raffa P. (a cura di). Connettere. Un disegno per annodare e tessere. Linguaggi Distanze Tecnologie. Atti del $42^{\circ}$ Convegno Internazionale dei Docenti delle Discipline della Rappresentazione/Connecting. Drawing for weaving relationship. Languages Distances Technologies. Proceedings of the $42^{\text {th }}$ International Conference of Representation Disciplines Teachers. Milano: FrancoAngeli, pp. 963-978. 